\title{
Intelligent Rule Firewall berbasis Linux menggunakan Association Rule Mining untuk Peningkatan Adaptive Response Attack
}

\author{
Slamet $^{1}$, Norma Ningsih ${ }^{2}$ \\ ${ }^{1,2}$ Program Studi/Jurusan Sistem Informasi, Universitas Dinamika \\ Email: slamet@dinamika.ac.id*,norma@dinamika.ac.id
}

\begin{abstract}
Abstrak: Kompleksitas jaringan dan kebutuhan transaksi bisnis yang berkembang membuat organisasi harus semakin terbuka terhadap dunia, sehingga potensi serangan dari dalam dan dari luar jaringannya semakin meningkat. Salah satu mekanisme perlindungan yang serius dan murah adalah dengan menerapkan firewall berbasis linux untuk menjaga pintu masuknya serangan. Umumnya, fitur dasar firewall tidak efektif untuk menjaga serangan yang dinamis dan terjadi terus-menerus, sehingga diperlukan sistem firewall cerdas agar bisa adaptif terhadap jenis serangan dan kondusif terhadap kondisi paket terkini. Pada dasarnya, konfigurasi firewall menerima atau menolak tindakan untuk paket secara default. Dalam paper ini, peneliti mengusulkan untuk menambahkan kecerdasan buatan pada rule konfigurasi firewall default. Log firewall sebagai representasi keluar masuknya trafik diolah menggunakan Association Rule Mining. Hasilnya, (a) rule firewall mampu adaptif terhadap perilaku serangan di jaringan, (b) firewall mampu membuat sekaligus memperbaiki rule kebijakan dirinya dari paket-paket anomali sehingga dapat diterapkan sebagai konfigurasi firewall yang efektif.
\end{abstract}

Kata Kunci: rule firewall, linux, cerdas, association rule

\begin{abstract}
The complexity of network and the growing need for business transactions make organizations have to be more open to the world, so that the potential for attacks from inside and outside their network is increasing. One serious and inexpensive protection mechanism is to implement a linux-based firewall to guard against the entrance of attacks. The basic features of the firewall are not effective in preventing attacks that occur continuously and dynamically, so an intelligent firewall system is needed to be adaptive to the types of attacks and the real time packet conditions. Basically, Firewall sets accept or reject actions for packets by default. In this paper, the researcher proposes to add artificial intelligence in the firewall. Firewall logs as a representation of the entry and exit of traffic are processed using data association rule mining. As a result, (a) the firewall can be adaptive to the behavior of attacking on the network, $(b)$ the firewall is able to create and fix its own policy rules and anomalous packets so that it can be applied as an effective firewall configuration.
\end{abstract}

Keywords: rule firewall, linux, intelligent, association rule

\section{PENDAHULUAN}

Saat ini, infrastruktur siber dianggap sebagai aset terbesar bagi banyak organisasi sehingga pertahanan menjadi fokus perhatian utama. Untuk tujuan ini, organisasi menggunakan mekanisme pertahanan, termasuk firewall yang menjadi persyaratan utama untuk setiap sistem keamanan jaringan [1]. Firewall berbasis linux sering digunakan sebagai firewall oleh banyak perusahaan karena dapat digunakan secara gratis dan menawarkan fungsionalitas customized untuk mendeteksi ancaman atau peringatan umum [2]. Deteksi ancaman didapatkan dengan membuat rule dasar pada lalu lintas jaringan tertentu dan menganalisis statistik paket data yang melewatinya. Cara ini menghasilkan statistik informasi dengan volume yang besar tentang peristiwa keamanan yang dapat digunakan untuk analisis lebih lanjut. Namun sesungguhnya deteksi ancaman hanyalah fungsi dasar, sehingga membutuhkan kecerdasan tambahan dalam mengotomatisasi ekstraksi informasi firewall ini.
Selama ini cara otomatis ditawarkan oleh pihak ketiga dengan menggunakan alat yang mahal dan tidak bisa dikustomisasi oleh pengguna [3]. Oleh karena itu, perlindungan terhadap ancaman-ancaman keamanan hanya bersifat statis dan tidak bisa diekplorasi lagi. Teknologi firewall berada di garis depan dalam mengamankan jaringan. Apabila aturan (rule) firewall yang dikonfigurasi buruk maka menyebabkan efektivitas keamanan firewall menjadi terbatas. Issue utama dalam cara pengaturan ini adalah tentang seberapa banyak rule yang penting, berguna, up-to-date, dan terorganisir dengan baik sebagai cermin karakteristik dan volume paket di dalam jaringan saat ini. Namun yang sering terjadi adalah trend lalu lintas jaringan saat ini yang dinamis tidak diikuti dengan konfigurasi firewall yang dinamis. Log server seringkali menunjukkan bukti bahwa beberapa rule firewall sudah out-of-date atau tidak berguna lagi (usang) karena trafik yang dinamis, sehingga Network Administrator harus menghapus, 
menggabungkan, atau menyusun ulang rule untuk mengoptimalkan kebijakan dan efektifitas firewall.

Fungsi Association Rule Mining kepada log trafik jaringan dapat mengungkapkan ketidak-sesuaian rule firewall saat ini seperti contoh: update konten website melalui link SSH atau mengizinkan lalu lintas terlarang melalui perangkat di belakang firewall. Selain itu, dikarenakan jumlah rule filtering yang meningkat dan diatur dengan proses manual, pengelolaan rule kebijakan firewall menjadi sangat sulit dan memakan waktu yang lama.

Untuk menjawab kebutuhan akan manajemen firewall yang efektif, optimal dan dapat memvalidasi rule firewall secara otomatis, dibutuhkan sebuah teknik keamanan dan manajemen rule yang efektif juga. Untuk menjembatani kesenjangan ini, hal pertama perlu dilakukan pengamatan di jaringan dengan menganalisis trafik paket data menggunakan Association Rule Mining.

Penelitian ini menganalisis dan mengelola rule kebijakan firewall, tidak hanya dengan meminimalkan rule, tetapi juga untuk menghasilkan seperangkat rule efisien yang mencerminkan tren lalu lintas terkini. Selanjutnya dengan memberikan kemampuan pembaruan kebijakan secara real time dari firewall (misalnya, dapat mendeteksi banyaknya serangan DDOS pada web server, Sniffing pada DNS Server).

\section{METODE PENELITIAN}

Metode penelitian ini dimulai dengan penjelasan dasar firewall, intelligent rule firewall, algoritma association rule maining dan algoritma apriori.

\section{Dasar Firewall}

Firewall adalah perangkat lunak atau sistem perangkat keras yang menyaring lalu lintas jaringan sesuai dengan kebijakan yang telah ditentukan sebelumnya. Untuk ini, firewall ditanamkan di tempat penting dari sistem operasi atau di posisi kunci dari arsitektur jaringan. Di posisi ini, firewall menganalisis apa yang terjadi melalui dan menerapkan tindakan dengan seperangkat rule.

Secara umum, fungsional firewall dapat memproses paket yang masuk atau keluar berdasarkan kebijakan yang telah dikonfigurasi sebelumnya. Kebijakan diwakili oleh seperangkat rule yang menentukan apa yang harus dilakukan dengan paket tertentu: apakah paket tersebut diizinkan/dilewati, atau dibuang (dengan atau tanpa pemberitahuan).

Biasanya, ada 3 tindakan (action) dasar yang dilakukan firewall terhadap paket data tersebut. Tindakan ini adalah bagian dari definisi rule [4]. Setiap rule menentukan satu tindakan. Tindakan memiliki nama yang cukup jelas. Tindakan ALLOW (atau ACCEPT) mengizinkan paket untuk melewati firewall masuk atau keluar (tergantung pada arah lalu lintas). Tindakan ini adalah tindakan default, seperti apabila firewall tidak dipasang. Tindakan DENY (atau DROP) akan menjatuhkan paket tanpa pemberitahuan kepada pengirim. Tindakan ini adalah tindakan yang paling berguna. Tindakan REJECT, mirip dengan DENY, melarang paket lewat, tetapi dengan pemberitahuan yang dikirim kembali kepada pengirim. Fungsionalitas firewall secara umum dapat dilihat pada gambar 1, dimana paket dari server akan dilakukan filtering sebelum menuju ke client. Demikian juga sebaliknya untuk paket yang berasal dari client yang menuju ke server.

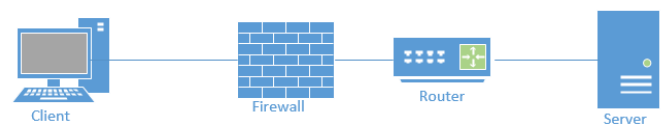

Gambar 1. Fungsi dasar Firewall

Sedangkan aturan-aturan (rules) umum yang sering digunakan oleh firewall merujuk pada área-area seperti IP sumber, IP tujuan, port sumber, port tujuan, mask sumber, mask tujuan, action dan protokol yang digunakan untuk melakukan filtering, sebagaimana dijelaskan pada tabel 1 .

Tabel 1. Area umum dalam firewall:

\begin{tabular}{ll}
\hline Area & Keterangan \\
\hline IP Sumber & $\begin{array}{l}\text { Alamat IP sumber yang cocok } \\
\text { dengan rule }\end{array}$ \\
& $\begin{array}{l}\text { Alamat IP tujuan yang cocok } \\
\text { dengan rule }\end{array}$ \\
Port Sumber & $\begin{array}{l}\text { Alamat Port sumber yang cocok } \\
\text { dengan rule }\end{array}$ \\
Port Tujuan & $\begin{array}{l}\text { Alamat Port tujuan yang cocok } \\
\text { dengan rule } \\
\text { Alamat Mask sumber yang } \\
\text { cocok dengan } \text { rule }\end{array}$ \\
Mask Tujuan & $\begin{array}{l}\text { Alamat Mask tujuan yang cocok } \\
\text { dengan rule } \\
\text { Accept, Deny atau Reject } \\
\text { Action }\end{array}$ \\
Protokol & UDP \\
\hline
\end{tabular}

\section{Intelligent Rule Firewall}

Intelligent Rule Firewall adalah firewall umum yang dilengkapi dengan kemampuan untuk melakukan rule filtering, memindai, dan mencari aktivitas yang berpotensi berbahaya, kemudian mengirimkan peringatan untuk memberi tahu administrator tentang ancaman yang masuk ke jaringan sehingga dapat segera didiagnosis masalahnya. Alat ini juga memiliki kemampuan untuk menegakkan kebijakan internal seperti mencegah pemakai menjelajahi dan mengakses situs web yang berpotensi berbahaya atau terlarang di tempat kerja. Artificial Intelligent digunakan sebagai pembelajaran di dalam rule firewall untuk melacak catatan serangan secara otomatis dan mencegah tindakan serupa di masa depan [5]. Algoritma yang digunakan dalam intelligent rule firewall pada penelitian ini adalah Algoritma Association Rule Mining (ARM) dan Algoritma Apriori. Flow Diagram dari Intelligent Rule Firewall dapat dilihat pada gambar 2. 


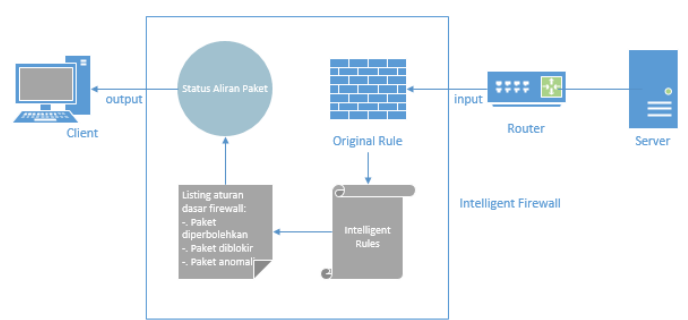

Gambar 2. Flow Diagram Intelligent Rule Firewall

Pada gambar 2, trafik data yang berasal dari server menuju client, melewati sebuah router terlebih dahulu, sebelum dilakukan filtering di dalam firewall yang sudah dilengkapi dengan sistem cerdas. Paket yang masuk ke dalam firewall diolah menggunakan teknik mining untuk menghasilkan rule terbaik dan adaptif.

Selanjutnya, paket dari firewall akan diteruskan kepada client untuk dieksekusi. Apabila aturannya memperbolehkan, maka paket akan diberikan kepada client. Paket akan diblokir apabila tidak diperkenankan oleh rule firewall. Apabila terdapat paket anomali, data akan diolah kembali untuk menghasilkan pola dan rule terbaik yang bisa dimasukkan sebagai usulan tambahan untuk rule terbaru.

\section{Algoritma Association Rule Mining}

Association Rule adalah pernyataan if/then yang membantu untuk mengungkap hubungan antara data yang tidak terkait dalam basis data, basis data relasional atau repository informasi lainnya [6]. Aturan asosiasi digunakan untuk menemukan hubungan antara bendabenda yang sering digunakan bersama-sama. Penggunaan Association Rule seperti analisis data dalam basis data, klasifikasi, cross marketing, clustering, desain katalog, analisis lost-leader dan sebagainya. Sebagai contoh misalnya, jika pelanggan membeli roti maka dia mungkin juga membeli mentega. Jika pelanggan membeli laptop maka dia mungkin juga membeli kartu memori.

Ada dua kriteria dasar yang digunakan oleh association rule yaitu support dan confidence. Dua kriteria ini menghasilkan identifikasi hubungan dan aturan dengan menganalisis if/then yang sering digunakan oleh pola. Association rule biasanya diperlukan untuk memenuhi dukungan minimum yang ditentukan pengguna dengan confidence minimum pada saat yang sama.

Rule $: X=>\left\{\begin{array}{l}\text { Support }=\frac{f r q(X, Y)}{N} \\ \text { Confidence }=\frac{f r q(X, Y)}{N}\end{array}\right.$

\section{Support}

Support pada Association Rule Mining didefinisikan sebagai persentase record yang berisi $X \tilde{U}$ $Y$ terhadap jumlah total record dalam basis data [6]. Hitungan untuk setiap item bertambah satu setiap kali item ditemukan dalam transaksi berbeda $(T)$ di basis data (D) selama proses pemindaian. Hal ini berarti jumlah support tidak memperhitungkan jumlah item. Contoh sederhana, misalnya dalam sebuah transaksi seorang pelanggan membeli tiga botol air mineral akan ditambahkan support berjumlah satu air mineral saja. Dengan kata lain, jika transaksi berisi item maka jumlah dukungan item ini bertambah satu. Support dihitung dengan rumus berikut:

$$
\operatorname{Support}(X, Y)=\frac{\text { Jumlah Support dari } X Y}{\text { Total Transaksi pada D }}
$$

Dapat dilihat bahwa support dari suatu item adalah signifikansi statistik dari association rule. Misalkan support suatu barang adalah $0,1 \%$, artinya hanya 0,1 persen transaksi yang mengandung pembelian barang ini. Pembeli tidak akan terlalu memperhatikan jenis barang yang tidak begitu sering dibeli, karena diperlukan dukungan yang tinggi untuk association rule yang lebih menarik. Sebelum proses mining, pengguna dapat menentukan support minimum sebagai threshold, yang berarti mereka hanya tertarik pada aturan asosiasi tertentu yang dihasilkan dari kumpulan item yang support-nya melebihi threshold itu. Namun, terkadang itemset tidak sesering yang didefinisikan oleh threshold, sehingga association rule yang dihasilkan darinya masih penting.

\section{Confidence}

Confidence didefinisikan sebagai persentase jumlah transaksi yang mengandung $X \tilde{U} Y$ terhadap total jumlah record yang mengandung $X$, dimana jika persentase tersebut melebihi threshold dari confidence maka dapat dihasilkan aturan asosiasi $\mathrm{X} \rightarrow \mathrm{Y}[6]$.

$$
\text { Confidence }(X \mid Y)=\frac{\text { Support dari }(X Y)}{\text { Support dari } X}
$$

Confidence adalah ukuran kekuatan aturan asosiasi, misalkan confidence aturan asosiasi $\mathrm{X} \rightarrow \mathrm{Y}$ adalah $60 \%$, artinya $60 \%$ dari transaksi yang mengandung $\mathrm{X}$ juga bersama-sama mengandung $\mathrm{Y}$, demikian pula untuk memastikan aturan dengan confidence minimum juga bisa ditentukan sebelumnya oleh pengguna.

\section{Algoritma Apriori}

Algoritma Apriori digunakan untuk melakukan mining kepada kumpulan item yang sering (frequently) dan association rule learning. Algoritma ini menggunakan pencarian level-wise, dimana k-itemsets (Sebuah itemset yang berisi item yang dikenal dengan $k$ ) digunakan untuk mengeksplorasi $(k+1)$-itemsets, melakukan mining itemset yang sering (frequently) dari transaksional basis data pada boolean association rule.

Dalam algoritma ini, himpunan bagian yang sering diperpanjang satu item pada saat yang sama. Langkah ini dikenal sebagai proses pembangkitan (generate) kandidat, selanjutnya kelompok kandidat itu diujikan kepada data tertentu. Untuk menghitung calon set item secara efisien, Apriori menggunakan metode breadth-first search dan hash tree structure [7]. Cara ini 
digunakan untuk mengidentifikasi item individu yang sering berada di basis data dan memperluasnya ke set item yang lebih besar sebagai set item yang sering muncul di basis data. Algoritma Apriori menentukan set item yang sering muncul dan dapat digunakan untuk menentukan aturan asosiasi yang menjadi tren umum di dalam basis data.

Apriori:

Berikut ini adalah prosedur untuk algoritma

$C I_{k}$ : Candidate itemset having size $k$

$F I_{k}:$ Frequent itemset having size $k$

$F I_{1}=\{$ frequent items $\}$;

For $\left(k=1 ; F I_{k} !=\right.$ null; $\left.k++\right)$ do begin

$\mathrm{CI}_{k}+1=$ candidates generated from FIk;

For each transaction $t$ in database $D$ do

Increment the count value of all candidates in

$C I_{k}+1$ that are contained in $t$

$\mathrm{FI}_{k}+1=$ candidates in CIk+1 with min_support

End

Return $\mathrm{FI}_{k}$;

Proses penelitian yang dilakukan pada paper ini terdiri dari empat iterasi, yaitu: (1). Mengumpulkan data mentah dari log firewall menggunakan tools TCPDump yang ada di linux, (2). Melakukan Pre-Processing dengan mengekstraksi atribut dari log firewall menggunakan Algoritma Association Rule Mining dan Algoritma Apriori untuk menghasilkan rule awal, (3). Untuk menemukan kumpulan rule awal pada firewall digunakan Filtering Rule Generalization (4) Melakukan perbaikan rule dengan mengidentifikasi rule yang out-ofdate dan rule yang terbaik. Hasil identifikasi terbaik digunakan sebagai perbaikan rule firewall yang sudah ada. Framework penelitian dapat dilihat pada gambar 3 .

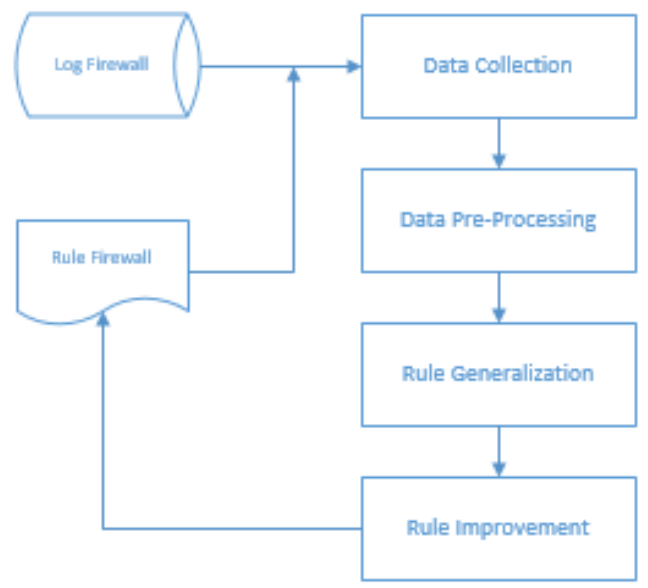

Gambar 3. Framework Penelitian

\section{HASIL DAN PEMBAHASAN}

Pada bagian ini dijelaskan dua hal yaitu: a. proses dan analisis dataset; $b$. proses pembuangan rule yang membusuk (usang) dan pemakaian rule yang dominan pada konfigurasi firewall.

\section{A. Proses dan Analisis Dataset A.1 Data Collection}

Pada tahap pertama memproses kebijakan aturan (rule) firewall yang diambil dari log file trafik data di dalam firewall linux. Tercatat sebanyak 40.150 catatan dari $\log$ firewall Linux. Untuk mengurangi jumlah status penelitian dan prototipe, kami hanya menggunakan area penting dalam rule firewall dan header paket IP seperti: protokol (TCP atau UDP), arah paket (masuk atau keluar), alamat IP sumber, port sumber, alamat IP tujuan, port tujuan, dan tindakan (Deny/Drop/Accept). Setiap rule terdiri dari atribut dalam format berikut $"\langle$ direction $\rangle\langle$ protocol $\rangle\langle$ source-IP> $\langle$ source-port $\rangle$ $\langle$ dest-IP> $\rangle$ dest-port $\rangle\langle$ action $\rangle "$. Tidak adanya atribut di atas dalam rule menunjukkan bahwa rule tersebut tidak dipengaruhi oleh atribut tersebut.

Daftar rule firewall Linux yang digunakan pada penelitian ini ditunjukkan pada skrip berikut.

\#!/bin/bash

\# Clear any previous rules.

/sbin/iptables $-F$

\# Default drop policy.

/sbin/iptables -P INPUT DROP

/sbin/iptables -P OUTPUT ACCEPT

\# Allow anything over loopback and vpn.

/sbin/iptables -A INPUT -i lo -s 127.0.0.1 -d 127.0.0.1 -j ACCEPT

/sbin/iptables -A OUTPUT -o lo -s 127.0.0.1 -d 127.0.0.1 -j ACCEPT

/sbin/iptables -A INPUT -i tunO -j ACCEPT

/sbin/iptables -A OUTPUT -o tunO -j ACCEPT

/sbin/iptables -A INPUT - $p$ esp -j ACCEPT

/sbin/iptables -A OUTPUT - p esp -j ACCEPT

\# Drop any tcp packet that does not start a connection with a syn flag. /sbin/iptables -A INPUT -p tcp! --syn -m state --state NEW -j DROP

\# Drop any invalid packet that could not be identified.

/sbin/iptables -A INPUT -m state --state INVALID -j DROP

\# Drop invalid packets.

/sbin/iptables $\quad-A \quad I N P U T \quad-p \quad t c p \quad-m$ tcp $\quad$--tcp-flags FIN,SYN,RST,PSH,ACK,URG NONE -j DROP

/sbin/iptables -A INPUT -p tcp -m tcp --tcp-flags SYN,FIN SYN,FIN -j DROP

/sbin/iptables -A INPUT -p tcp -m tcp --tcp-flags SYN,RST SYN,RST -j DROP

/sbin/iptables -A INPUT -p tcp -m tcp --tcp-flags FIN,RST FIN,RST -j DROP

/sbin/iptables -A INPUT -p tcp -m tcp --tcp-flags ACK,FIN FIN -j DROP

/sbin/iptables -A INPUT -p tcp -m tcp --tcp-flags ACK,URG URG -j DROP

\# Reject broadcasts to 224.0.0.1

/sbin/iptables -A INPUT -s 224.0.0.0/4 -j DROP

/sbin/iptables - A INPUT -d 224.0.0.0/4 -j DROP

/sbin/iptables -A INPUT -s 240.0.0.0/5 -j DROP

\# Blocked ports

/sbin/iptables -A INPUT -p tcp - $m$ state --state NEW,ESTABLISHED,RELATED --dport 8010 -j DROP

\# Allow TCP/UDP connections out. Keep state so conns out are allowed back in.

/sbin/iptables -A INPUT -p tcp -m state --state ESTABLISHED -j ACCEPT

/sbin/iptables -A OUTPUT -p tcp -m state --state NEW,ESTABLISHED -j ACCEPT

/sbin/iptables -A INPUT -p udp -m state --state ESTABLISHED -j ACCEPT

/sbin/iptables -A OUTPUT $-p \quad u d p \quad-m$ state - -state NEW,ESTABLISHED -j ACCEPT

\# Allow only ICMP echo requests (ping) in. Limit rate in. Uncomment if needed.

/sbin/iptables -A INPUT -p icmp -m state --state NEW,ESTABLISHED --icmp-type echo-reply -j ACCEPT

/sbin/iptables -A OUTPUT - $p$ icmp $-m$ state --state NEW,ESTABLISHED --icmp-type echo-request -j ACCEPT

\# or block ICMP allow only ping out 
/sbin/iptables -A INPUT -p icmp -m state --state NEW -j DROP /sbin/iptables -A INPUT -p icmp -m state --state ESTABLISHED -j ACCEPT

/sbin/iptables -A OUTPUT $-p \quad$ icmp $\quad-m$ state $\quad$--state NEW,ESTABLISHED -j ACCEPT

\# Allow ssh connections in.

\#/sbin/iptables -A INPUT -p tcp -s 1.2.3.4 -m tcp --dport 22 -m state -state NEW,ESTABLISHED,RELATED -m limit --limit $2 / m$-j ACCEPT

\# Drop everything that did not match above or drop and log it.

\#/sbin/iptables -A INPUT $-j$ LOG $\quad$--log-level 4 --log-prefix "IPTABLES_INPUT:"

/sbin/iptables -A INPUT -j DROP

\#/sbin/iptables -A FORWARD -j LOG --log-level 4 --log-prefix "IPTABLES_FORWARD: "

/sbin/iptables -A FORWARD -j DROP

\#/sbin/iptables -A OUTPUT -j LOG "IPTABLES_OUTPUT: "

/sbin/iptables -A OUTPUT -j ACCEPT

iptables-save $>/$ dev/null $2>\& 1$

\section{A.2 Data Pre-Processing}

Tahap kedua memproses dataset dengan mengekstraksi fitur paket dari log firewall menggunakan algoritma Association Rule Mining dan algoritma Apriori. Setiap baris dataset log firewall menunjukkan informasi setiap paket dalam: jangka waktu, action (DROP_LOGIN), arah (OUT=), alamat IP sumber (SRC=), IP tujuan (DST=), ukuran paket $(\mathrm{LEN}=)$, waktu berangkat $(\mathrm{TTL}=)$, ID paket $(\mathrm{ID}=)$, protokol $(\mathrm{PROTO}=)$, port sumber $(\mathrm{SPT}=)$, dan port tujuan $(\mathrm{DPT}=)$. Hasil sebagian dari proses untuk Alamat IP 202.110.* ditunjukkan pada gambar 4.

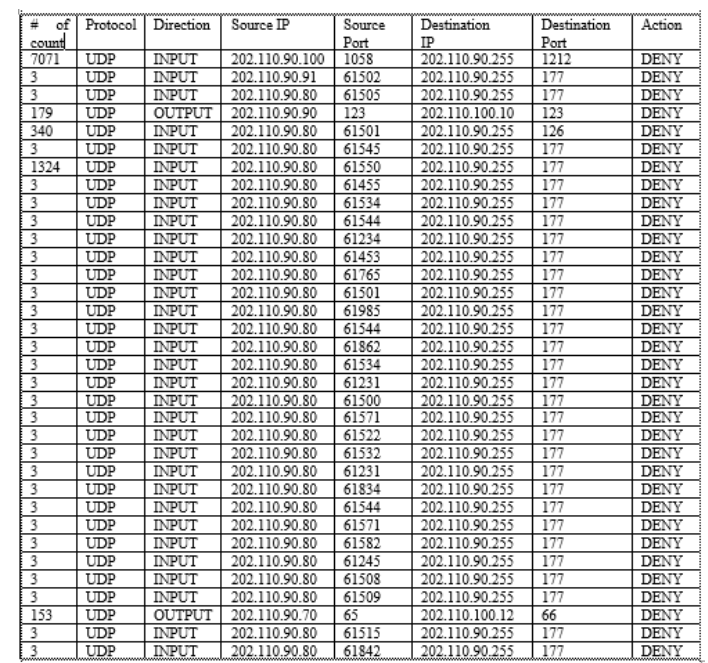

Gambar 4. Contoh Rule Filtering dari Pre-processing

\section{A.3 Rule Generalization}

Tahap ketiga adalah menggeneralisasi rule menggunakan Filtering Rule Generalization. Pada langkah ini, setiap rule dasar dengan frekuensi tertentu digeneralisasikan atau diagregasi lebih mendalam. Misalnya, alamat IP dalam rule dapat berupa host tertentu (alamat IP unik seperti 202.110.90.100) atau menghasilkan alamat jaringan gabungan (misalnya 202.110.90.*) dengan menggabungkan sekelompok rule serupa dengan rule yang sama (Alamat IP). Port dapat berupa nomor port tunggal tertentu atau digabungkan menjadi "anything" untuk menjadi nomor port apa pun.
Untuk membagi rule pemfilteran multi-value menjadi beberapa rule dimana setiap rule memiliki bidang bernilai tunggal. Atribut terdiri dari tujuh area untuk menganalisis dan menemukan pengetahuan dari $\log$ trafik data dimana instance-nya adalah informasi paket dari log file firewall. Rule dikelompokkan dari semua rule yang diidentifikasi dan digeneralisasi dalam superset. Misalnya, mengelompokkan semua rule IP alamat 202.110.90.80 (apakah itu IP sumber atau IP tujuan) dengan port tujuan (=21), dan action (=accept) adalah menghasilkan rule yang ditunjukkan pada gambar 5 .

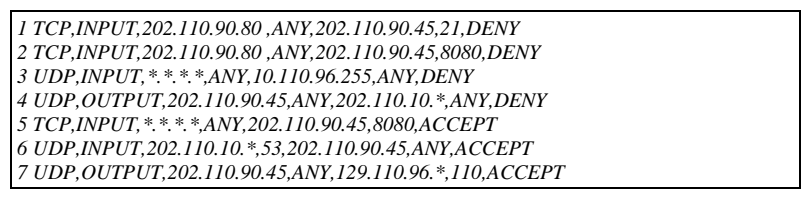

Gambar 5. Generalisasi rule (aturan)

\section{A.4 Rule Improvement}

Pada tahap ini, pertama-tama dilakukan penggabungan rule kebijakan yang ditemukan dari log file dari rule awal firewall. Penggabungan rule yang dihasilkan (15 rule) dapat dilihat pada gambar 6.

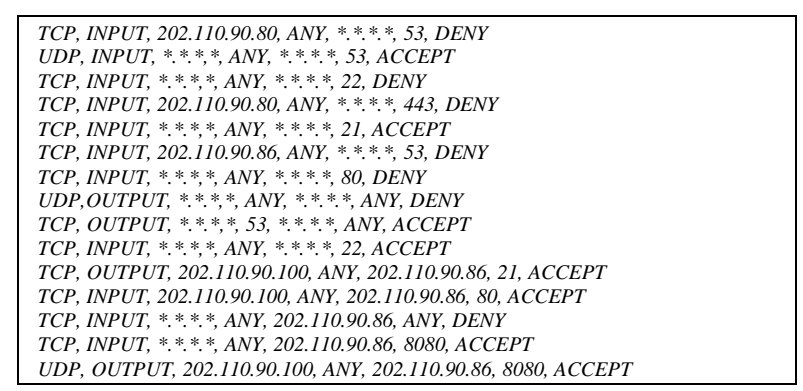

Gambar 6. Rule Kebijakan Gabungan Firewall

Langkah selanjutnya adalah mendeteksi kebijakan anomali dari rule firewall gabungan seperti yang ditunjukkan pada Gambar. 7.

\footnotetext{
Rule 1, Rule 2: $\Rightarrow>$ Generalisasi

Rule 1, Rule 14: $=>$ Shadowed

Rule 2, Rule 1: $\Rightarrow>$ Korelasi

Rule 2, Rule 12: $=>$ Generalisasi

Rule 3, Rule 5: $\Rightarrow>$ Shadow

Rule 4, Rule 7: $\Rightarrow>$ Shadow

Rule 4, Rule 5: $\Rightarrow>$ Generalisasi

Rule 5, Rule 7: $\Rightarrow>$ Generalisasi

Rule 7, Rule 5: $\Rightarrow>$ Korelasi

Rule 8, Rule 2: $\Rightarrow>$ Shadowed

Rule 10, Rule 12: $\Rightarrow$ Korelas

Rule 12, Rule 1: $\Rightarrow>$ Generalisasi

Rule 13, Rule 12: $\Rightarrow$ Generalisasi

Rule 14, Rule 12: $=>$ Shadow

Rule 14, Rule 13: => Generalisasi
}

Gambar 7. Output Algoritma Deteksi Anomali

Dengan menggunakan pencarian trafik anomali, telah dideteksi 7 rule generalisasi, 3 rule korelasi, dan 5 rule shadowed. Beberapa rule yang terdeteksi ini, dimanfaatkan untuk dua hal. Pertama, digunakan sebagai dasar membuat rule umum untuk 
memperbarui rule kebijakan firewall. Kedua, digunakan sebagai dasar membuat rule yang lebih spesifik untuk rule final dari konfigurasi firewall. Cara ini digunakan untuk mendeteksi lalu lintas yang tidak diinginkan. Rule kebijakan firewall yang ada (dari 10 rule awal) digabungkan dengan rule umum (7 rule yang dihasilkan dari file log firewall (40.150 catatan paket)). Kemudian untuk mendeteksi anomali, terdapat 7 dari 15 rule digunakan untuk rule akhir firewall. Hasilnya adalah rule baru yang diinginkan, telah digeneralisasi dan bebas dari anomali sehingga menjamin kebenaran dan efisiensi konfigurasi dan proses filtering firewall.

\section{B. Rule Firewall yang dibuang dan Rule Firewall yang digunakan}

Salah satu pertanyaan menarik yang diteliti pada makalah ini adalah bagaimana rule firewall pada konfigurasi awal masih berguna dan efektif untuk pola lalu lintas jaringan saat ini. Jawaban dari pertanyaan ini adalah: (1) terdapat rule di dalam konfigurasi yang jarang atau tidak pernah dipakai. Rule ini disebut sebagai rule yang membusuk, dan akhirnya rule ini yang dibuang dari konfigurasi firewall. (2) rule yang dipakai di dalam konfigurasi adalah rule yang mendominasi dan sering digunakan, dimana rule ini sebagai representasi dari sebagian besar trafik jaringan.

Hasil dari eksperimen bahwa distribusi probabilitas log file firewall dari 40.150 paket ditunjukkan pada tabel 2 dan gambar 8 .

\begin{tabular}{|c|c|c|c|c|c|}
\hline No & Src-IP & $\begin{array}{l}\text { Src- } \\
\text { Port }\end{array}$ & Dst-IP & $\begin{array}{l}\text { Dst- } \\
\text { Port }\end{array}$ & Prob \\
\hline 1 & 202.110 .90 .80 & ANY & $* . * * * *$ & 80 & 0,0001 \\
\hline 2 & *.*.*.* & ANY & *.*.*.* & 80 & 0,0011 \\
\hline 3 & $* . * * * *$ & ANY & $* * * * *$ & 22 & 0,0451 \\
\hline 4 & 202.110 .90 .80 & ANY & *.*.*.* & 23 & 0,0201 \\
\hline 5 & $* . * * * *$ & ANY & *.*.*.* & 53 & 0,0301 \\
\hline 6 & 202.110 .90 .80 & ANY & $* * * *$ & 22 & 0,0501 \\
\hline 7 & $* * * * *$ & 22 & $* * * *$ & $\begin{array}{l}1024- \\
65535\end{array}$ & 0,3001 \\
\hline 8 & $* * * * *$ & $\begin{array}{l}1024- \\
65535\end{array}$ & $* * * * *$ & ANY & 0,0021 \\
\hline 9 & $* * * * *$ & ANY & $* * * * *$ & ANY & 0,0301 \\
\hline 10 & Tota & $\begin{array}{l}\text { ANY } \\
\text { obabilit }\end{array}$ & $* * * *$ & 53 & $\begin{array}{l}0,5201 \\
1\end{array}$ \\
\hline
\end{tabular}

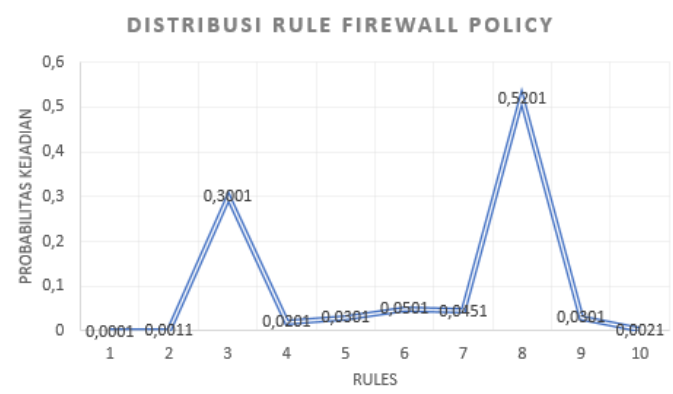

Gambar 8. Distribusi Paket pada Rules Filtering Awal

Gambar 8 menampilkan distribusi probabilitas setiap rule dari 10 rule firewall awal, di mana sumbu $\mathrm{x}$ adalah nomor urutan rule dan sumbu y adalah skala probabilitas. Rangking setiap rule berdasarkan frekuensi kemunculan rule di dalam log file firewall. Probabilitas kemunculan setiap paket dihitung sebagai berikut: $\mathrm{P}=\mathrm{f}$ / $\mathrm{N}$, dimana probabilitas (P) sama dengan frekuensi kemunculan paket (f) dibagi dengan jumlah total paket (N) yang tercatat dalam log file firewall.

Dalam percobaan yang dihasilkan selama satu minggu, didapatkan 10 rule awal dari log file firewall. Gambar 8 menunjukkan bahwa rule 3 dan rule 7 adalah rule yang dominan, mencakup lebih dari $70 \%$ lalu lintas jaringan, dan rule 1 bisa menjadi rule yang usang atau dibuang.

Untuk setiap rule dalam konfigurasi umum, ditemukan frekuensi masing-masing rule tertentu (sumber dan tujuan tertentu) yang digunakan untuk analisis lebih lanjut. Sebagai contoh, rule spesifik cocok dengan rule 3 sebagai salah satu rule paling banyak digunakan. Informasi ini membantu memperbarui urutan rule guna mengoptimalkan pencocokan pemfilteran secara real-time di firewall. Grafik pada gambar 8 adalah distribusi probabilitas dari rule 10 yang menghasilkan 16 rule.

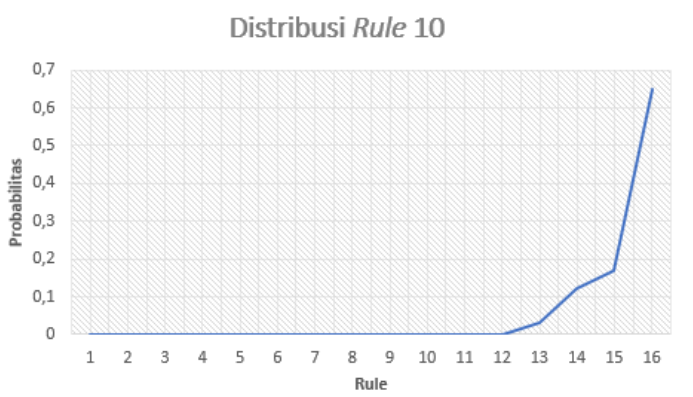

Gambar 9. Distribusi Paket pada Rules Filtering Awal

Sumbu $\mathrm{x}$ adalah sumbu setiap rule sesuai dengan urutannya dan sumbu y adalah skala probabilitas. Distribusi probabilitas dari setiap rule berbeda menggambarkan populasi pola lalu lintas jaringan yang tidak terdistribusi secara merata tetapi terkonsentrasi menjadi beberapa rule. Hal ini menjadi indikator yang positif dan kuat dengan berfokus pada beberapa rule unik. Dengan menyusun ulang atau memprioritaskan sebagian kecil dari rule firewall, seseorang dapat mengharapkan peningkatan kinerja dari fungsi firewall.

Dalam contoh ini, rule 16 menjadi kandidat pertama yang dianggap sebagai rule dominan. Sementara itu, rule 1 menjadi kandidat rule yang membusuk (rule kandidat yang akan dibuang) dari paket yang mengalir selama periode waktu tertentu, sebagaimana ditunjukkan pada gambar 10 . 


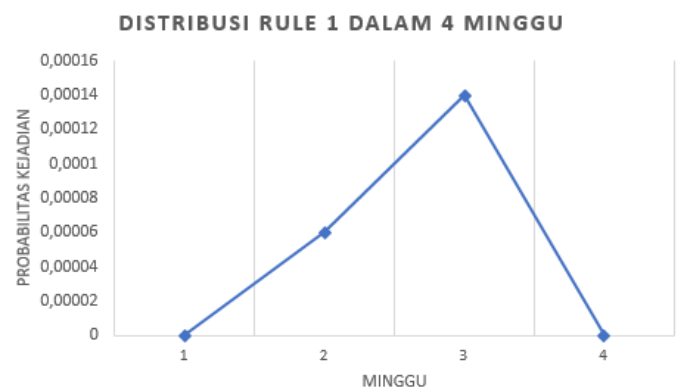

Gambar 10. Frekwensi Paket pada Rule 1 dalam 4 minggu

Gambar 10 menunjukkan distribusi probabilitas rule 1 yang ditambang (mining) dari file log yang dihasilkan setiap minggu selama sebulan, dimana sumbu $\mathrm{x}$ adalah dalam mingguan dan sumbu $\mathrm{y}$ adalah skala probabilitas.

Distribusi tersebut menegaskan kemungkinan rule yang mengikuti siklus hidup dan akhirnya membusuk setelah jangka waktu tertentu. Ini adalah salah satu indikator yang menjanjikan untuk mengkonfirmasi salah satu tujuan penelitian ini untuk menemukan rule yang membusuk dan memperbaharui rule firewall dalam waktu yang tepat. Rule yang tidak berguna dibuang dan rule yang mendominasi adalah rule yang mencakup bagian dari lalu lintas jaringan signifikan.

Dengan demikian telah didapatkan rule kebijakan yang lebih berguna, efektif dari rule firewall awal. Hal ini karena rule terakhir yang ada telah memberikan respon yang adaptif, dalam arti sudah sesuai dengan pola lalu lintas atau serangan (attacking) pada jaringan saat ini.

\section{KESIMPULAN DAN SARAN}

Dalam makalah ini, kami telah menyajikan proses baru dari pengelolaan kebijakan rule firewall, yang terdiri dari deteksi anomali, generalisasi dan perbaikan kebijakan menggunakan Algoritma Association Rule Mining dan dibantu Algoritma Apriori. Hasil yang dicapai: (a) rule mengambil data awal dari log firewall linux yang mencerminkan kapasitas tren lalu lintas jaringan saat ini, (b) membuat keputusan pola trafik data berupa analisis dasar dan deteksi anomali termasuk lalu lintas yang tersembunyi, (c) menggunakan teknik mining untuk menangani atribut diskrit dan real time agar beroperasi secara efisiensi dan fleksibel, dan (4) menganalisis rule firewall lama dan juga trafik anomali atau yang tersembunyi untuk mendapatkan rule yang lebih akurat dan efektif.

Kesimpulannya, rule mining ini terbukti bukan hanya salah satu dari pilihan yang layak, tetapi juga praktis, efektif dan optimal untuk diterapkan sebagai kebijakan rule firewall secara real time.

\section{DAFTAR PUSTAKA}

[1] K. Neupane, R. Haddad dan L. Chen, Next Generation Firewall for Network Security: A
Survey, Southeast Conf. 2018, 2018, pp. 1-6, doi: 10.1109/SECON.2018.8478973.

[2] M. G. Mihalos, S. I. Nalmpantis dan K. Ovaliadis, Design and Implementation of Firewall Security Policies using Linux Iptables, Journal of Engineering Science and Technology Review 12 (1) (2019) $80-86$.

(2021) The E-security Planet website. [Online], Top Threat Intelligence Platform 2021, https://www.esecurityplanet.com/products/threatintelligence-platforms/, tanggal akses: 16 Juni 2021.

[4] Kristian Valentin, Michal Maly, Network Firewall Using Artificial Neural Networks, Computing and Informatics, Vol. 32, 2013, 1312-1327

[5] Partha Chakraborty, Md. Zahidur Rahman, dan Saifur Rahman, Building New Generation Firewall Including Artificial Intelligence, International Journal of Computer Applications (0975 - 8887) Volume 178 - No.49, September 2019.

[6] Sanjay Rathee, Arti Kashyap, Adaptive-Miner: An Efficient Distributed Association Rule Mining Algorithm on Spark, Journal of Big Data, Springer (2018) 5:6, https://doi.org/10.1186/s40537-0180112-0.

[7] Ish Nath Jha, Samarjeet Borah, An Analysis on Association Rule Mining Techniques, Special Issue of International Journal of Computer Applications (0975 - 8887) International Conference on Computing, Communication and Sensor Network (CCSN) 2012.

[8] C. Wang, X. Zheng, Application of Improved Time Series Apriori Algorithm by Frequent Itemsets in Association Rule Data Mining Based on Temporal Constraint. Evolutionary Intelligent 13, Springer, 39-49 (2020). https://doi.org/10.1007/s12065-01900234-5 